study of the industry over a great many years. Constant changes among senior men would do a Research Association a great deal of harm.

As regards research being run by committees, while it is true that research committees do exist, and that they approve the research programme, I have never heard of a case where fundamental scientific work has been hindered through this system. From the very constitution of these committees, the suggestions which come from them are, so far as my knowledge goes, nearly always concerned with applications of knowledge the Association has already gained-a field in which they are eminently qualified to make suggestions, often valuable ones.

Sir Lawrence's suggestion that there should be more contacts between research workers in the universities and those in industry has great possibilities. I would therefore extend a cordial invitation to any professors who feel an urge to write about Research Associations, but who may possibly feel that before doing so they would like to know more about them, to visit the Shirley Institute, and form their own opinion of the purely scientific researches carried on there normally in peace-time.

$$
\text { F. C. ToY. }
$$

British Cotton Industry Research Association, Shirley Institute,

Didsbury,

Manchester. Sept. 1.

I AM too conscious of the lack of contact which has often existod between the university and the industrial researcher not to sympathize with much of what Dr. Toy says on the functions of the Research Associations, and one cannot resent the mild sting which he has permitted himself to add to its tail !

$\mathrm{He}$ mentions two difficulties with which the Research Associations have to contend: lack of resources and the fact that for the most part they serve the older industries. As regards the first, it has often been pointed out what a small fraction of our national income we devote to research, as compared with other industrialized countries. As regards the second point, the older industries have a wealth of technical experience, and it is an arduous task for the man of science, using his fundamental knowledge, to surpass the skill and lore aequired by long practice.

Dr. Toy rightly stresses the undoubted fact that in spite of these handicaps much fine original work is done in the Research Associations. Yet on rereading my own article, I do not feel that Dr. Toy's views are in conflict with its main points, and hope that readers of NATURr will come to the same conclusion. In discussing physics in industry, the last thing $I$. had in mind was a criticism of any particular body of mon. I expressed a conviction, and rea:firm it, that we have not yet discovered the hest way of applying our great resources of native sciontific ability to the strengthening of our industrial position.

W. L. BraGG.

\section{Encouragement of Research in Industry}

The point made by Sir Lawrence Bragg ${ }^{1}$, and again by Mr. Benham², concerning the need for freedom for scientific work from other interferences, cannot be too highly stressed.

The fact that scientific workers are generally blessed with a good fund of 'common sense' often results in many jobs in industrial establishments being passed over to thern for attention. jobs which more properly should be dealt with by other departments of the organization. Their greater technical knowledge of the jobs means that they are better donebut only at the cost of interruption of their proper research or development work. Too often also they are called upon to put right the mistakes of other sections of the business-mistakes which should not have occurred if adequately trained staff had been employed in those sections. Financial considerations, however, doubtless influence this in many instances.

Reluctance of the production staffs to make use of the developments of the research workers is not confined to the senior supervising staff. In many cases it extends down to the foremen, to the charge hands and to the workers themselves. It can only be overcome by the friendliest co-operation between both sections. This co-operation is seldom easy to secure, because they generally talk in different 'languages', and think in different terms.

A good liaison engineer (but one who has no particular flair for research), between the development or research section and the production departments, is probably the best solution. If he has had a little post-graduate research training he will appreciate the finer points and needs of the scientific aspects of the problem; while if he is a good engineer he will be able to translate these into the necessary applications in the manufacturing departments and see that their difficulties - and they will always have difficulties with any new process - are given sympathetic attention.

The suggestion made by Mr. Benham that more use should be made of shorthand typists in research laboratories is a good one, and I should like to endorse it heartily. Provided that they are reasonably intelligent and can be trained to present the data in a proper form and can take some useful action regarding other matters on which they may be given notes during the progress of some investigation, they can be a great asset. Good ones for this type of work are not easy to find. I would suggest further that if mechanical calculating aids are available-and at the very least an adding machine should be 'on tap' in every laboratory-they should be taught to operate them so that their sphere of utility to the research worker can be much increased. In many cases, however, it does not prove easy to convince the management of needs such as these.

This, again, is another argument in favour of sir Lawrence I3ragg's plea that all laboratories should be given authority for certain expenditure entirely without reference to any outside control. The researchers will then quickly get the equipment most useful to them, withont the wearisome arguments necessary to justify it to others-who cannot appreciate the real needs of the moment. Only too often is work spoiled or improperly completed on this account.

Finally, as Mr. Benham says, give the researchers more responsibility. If expenditure on the research is justified at all, it is all the more justifiable that the researchers should be given the responsibility and authority to see that their work is properly applied in the production departments. They must rank equal with the production managers and not be entirely subordinate to them.

Nutteries,

Liss, Hants.

Philip R. Coursey.

1. NATURE, 149, 75 (1942)

2 NATURE, 150, 235 (1942). 